\title{
KRITIK ARKOUN ATAS EPISTEMOLOGI ISLAM
}

\author{
M. Solikhin \\ M. Fadholi \\ Peneliti UIN Walisongo Semarang \\ Email:masfadh@yahoo.com
}

\begin{abstract}
The root of Arkoun's epistemology of thought, originated from Arkoun's life that grew at the rapid development of science, both socio-humanities and the natural sciences of the Western world. This momentum is not wasted and left to pass without meaning. So it is not strange that in each of his writings thick with nuances of modern Western terms. The objective of the criticism raised by arkoun is to revive the dynamic and modern Islamic thought, to suit the development of various sciences. According to Arkoun, the understanding and exposure of Islamic studies, whether in the stage of introducing theory, creating concepts, or applying its teachings, must be explained using an interdisciplinary approach. Thus, Islamology can always be aligned with other scientific and rational modern sciences. Or in other languages, Arkoun aspires to an amalgamation of the most valuable element of Islamic reason and modern reason.
\end{abstract}

Keywords: Arkoun, Epistimology, Islam.

\begin{abstract}
Abstrak
Akar dari epistemologi pemikiran Arkoun, berawal dari kehidupan Arkoun yang tumbuh pada saat pesatnya perkembangan science, baik yang sosial-bumaniora maupun ilmu-ilmu alam di dunia Barat. Momentum ini tidak disia-siakan dan dibiarkan berlalu tanpa makna. Sehingga tidak aneb kalau dalam setiap tulisannya kental dengan nuansa istilah-istilah ilmu Barat Modern tersebut. Tujuan dari kritik-kritik yang dilontarkan arkoun adalab untuk menghidupkan kembali pemikiran Islam yang dinamis dan modern, agar sesuai dengan perkembangan berbagai ilmu pengetabuan. Menurut Arkoun, pemahaman dan pemaparan studi keislaman, baik dalam tahap memperkenalkan teori, menciptakan konsep, atau menerapkan ajaran-ajarannya, haruslah dijelaskan dengan menggunakan pendekatan interdisipliner. Dengan demikian, Islamologi dapat selalu disejajarkan dengan ilmu-ilmu modern lainnya yang ilmiah dan rasional. Atau dengan bahasa lain, Arkoun mencita-citakan suatu penggabungan unsur yang paling berharga dari nalar Islami dan nalar modern.
\end{abstract}

Kata Kunci: Arkoun, Epistimologi, Islam. 


\section{A. Pendahuluan}

Islam, secara telologis merupakan sistem nilai dan ajaran yang bersifat ilabiyyah-transenden. Akan tetapi dari sudut sosiologis dan historis, Islam merupakan fenomena peradaban, kultural yang bersinggungan dengan realitas sosial dalam kehidupan manusia. Dalam realitas sosialnya, Islam tidak lagi sekedar doktrin yang bersifat menjaman tetapi juga mengejawantah diri dalam institusi-institusi sosial yang selalu dipengaruhi oleh situasi dinamika ruang dan waktu (baca: sejarah). Dalam bahasa yang sederhana, Azumardi mengatakan bahwa Islam merupakan agama yang menyejarah. Pergumulan Islam dengan dinamika realitas sosial, selalu melahirkan ketegangan yang pada ujungnya tidak hanya menciptakan tantangan bagi umat Islam (yang peduli terhadap posisi Islam vis-à-vis) dalam realitas sosial kulturnya, tetapi juga dapat menciptakan konflik-konflik intelektual dan sosial antar umat Islam secara keseluruhan. Kondisi ini sering memunculkan berbagai tipologi gerakan dan pemikiran dalam Islam. Gelombang (baca:gerakan) pemikiran keislaman yang membahana dengan kencang di dunia Islam membuktikan, bahwa Islam sebagai sebuah diskursus akan mengalami diaspora yang tak terbendung. Munculnya bebagai corak gerakan pemikiran Islam dengan mengapresiasi realitas modern, ${ }^{1}$ dengan segala pranata sosialnya merupakan anak kandung sejarah yang terus bergerak melintasi zamannya,baik yang progresif-liberal maupun tradisional-tekstual. ${ }^{2}$

Dalam wacana pemikiran Islam kontemporer $^{3}$, penegasan seorang filsuf sekaligus penyair Muhammad Iqbal asal Pakistan tentang hakekat pemikiran, menurut

1 Realitas modern (baca kondisi zaman modern) ditandai oleh penggunaan rasio dalam kehidupan. Karena itu, pada dasarnya, pembaharuan atau modernisasi dalam Islam identik dengan rasionalisasi. Pemikiran rasional dalam Islam menurut Harun Nasution dipengaruhi oleh persepsi tentang tingginya kedudukan akal dalam Islam. Persepsi ini bertemu dengan persepsi yang sama dari Yunani yang sudah masuk ke dunia Islam. Tetapi jika pemikiran rasional Islam itu bersifat religius maka pemikiran rasional Yunani bercorak sekuler. Harun Nasution, Pembaharuan dalam Islam: Sejarab Pemikiran dan Gerakan (Jakarta: Bulan Bintang, 1975), hlm. 69.

${ }^{2}$ Moh. Shofan, Jalan Ketiga Pemikiran Islam (Yogyakarta: Ircisod, 2006), hlm. 17.

3 Gerakan pembaharuan pemikiran dengan berbagai coraknya adalah sebuah keniscayaan sejarah. Oleh karena itu gerakan pemikiran keislaman akan selalu mengikuti gerak sejarah yang terjadi saat itu. Sejarah sebagai unsur determinan dalam tataran empiriknya selalu mengiringi berbagai pemikiran keagamaan, karena itu, istilah Al-Qur'an "bi lisani qaumihi" merupakan sebuah proses negosiasi rasional, bahwa Islam sebagi doktrin dan norma harus dibahasakan dan selalu ditafsirkan sesuai dengan konteks dan sejarahnya. "Hakikatnya pemikiran tidaklah bersifat statis. Pemikiran senantiasa berwatak dinamis dan mendobrak keterbatasan (Mubammad Iqbal).” 
pemakalah sangatlah tepat jika dijadikan landasan berfikir dalam memahami kajian “pemikiran Islam” model Mehammed Arkoun( Johan Meuleman,1994:2) yang memiliki corak dan karakteristik serta keunikan tersendiri dalam khazanah kajian keislaman modern. Karakteristik dan keunikan yang dimiliki Arkoun itu mungkin karena posisi Arkoun sebagai salah satu tokoh di antara berbagai tokoh yang menekuni sejarah pemikiran keislaman dengan pendekatan-pendekatan post modernisme sebagai alat bantu analisis-analisisnya. ${ }^{5}$

Kalau diamati setiap tulisan yang dilahirkan Muhammad Arkoun, seorang muslim berpendidikan barat, agaknya tidak terlalu berlebihan untuk memposisikannya sebagai kritikus pemikiran Islam. Sikap kritis Arkoun diawali dengan rasa ketidakpuasannya terhadap situasi studi-studi keislaman baik di dunia Islam maupun Barat. ${ }^{6}$ Tujuan dari kritik-kritik yang dilontarkan arkoun adalah untuk menghidupkan kembali pemikiran Islam yang dinamis dan modern, agar sesuai dengan perkembangan berbagai ilmu pengetahuan. Menurut Arkoun, pemahaman dan pemaparan studi keislaman, baik dalam tahap memperkenalkan teori, menciptakan konsep, atau menerapkan ajaran-ajarannya, haruslah dijelaskan dengan menggunakan pendekatan interdisipliner. Dengan demikian, Islamologi dapat selalu disejajarkan dengan ilmu-ilmu modern lainnya yang ilmiah dan rasional. Atau dengan bahasa lain, Arkoun mencita-citakan suatu penggabungan unsur yang paling berharga dari nalar Islami dan nalar modern.?

Di dalam diskursus yang ditekuninya, telah ditemukan berbagai tatanan pemikiran Islam klasik dan motologi-mitologi yang menyesatkan. Arkoun menilai

4 Mohammed Arkoun adalah intelektual muslim kelahiran Taurrists-Nimoum Grande Kabillia, suatu daerah pegunungan berpenduduk Berber disebelah timur Aljir, al Jazair pada tanggal 1 Februari 1928. Sejak Arkoun menetap di Prancis, pengaruh berbagai perkembangan mutakhir dalam bidang Islamologi, filsafat, Ilmu bahasa, dan ilmu-ilmu sosial di dunia barat sangat jelas dalam karyakaryanya, sehingga Arkoun menjadi guru besar sejarah pemikiran Islam. Johan Meuleman dalam pengantar, Nalar Islami dan Nalar Modern: Berbagai tantangan dan Jalan baru Oleb Muhammed Arkoun, INIS, Jakarta, 1994, hlm. 2.

5 Zuhri, hadits dalam Pemikiran Arkoun, dalam Jurnal Studi Ilmu-ilmu Al-Qur'an dan Hadis vol. 6, No. 1, Januari 2005, hlm. 113.

${ }^{6}$ Sukri Iska, Rekontruksi Pemikiran Kritis Mohammed Arkoun dalam Jurnal Ta'dib, vol 2, No. 2, 1999, hlm. 13.

${ }^{7}$ Johan Meuleman, Islam dan Pasca Modernisme dalam Pemikiran Mohammed Arkoun dalam Tradisi, Kemodernan, dan Metamodernisme: Memperbincangkan Pemikiran Mohammed Arkoun, S.H. Meuleman (penyunting), Yogyakarta, LkiS, 1996, hlm. 119. 
bahwa pemikiran Islam, kecuali dalam beberapa usaha pembaharuan kritis yang bersifat sangat jarang dan mempunyai ruang perkembangan yang sempit sekali, belum membuka diri pada kemodernan pemikiran, sehingga tidak mampu menjawab tantangan yang dihadapi umat Islam kontemporer.

Menurut Arkoun pemikiran yang model tersebut dianggapnya naif karena pemikiran seperti itu dalam mendekati agama atas dasar kepercayaan langsung dan tanpa kritik. ${ }^{8}$ Oleh karena itu dengan jiwa kritisnya Arkoun melalui pendekatan dekonstruksi ${ }^{9}$ berusaha membongkar tatanan-tatanan yang dianggap baku oleh umat Islam, yakni pemikiran ortodoks yang ditulis dalam kitab-kitab klasik dan merombaknya dengan memberikan suatu tatanan pemikiran baru. Atau dengan bahasa yang lebih sederhananya bahwa Arkoun telah membentuk paradigma baru. Agaknya dengan cara seperti ini, dia dapat dikatakan telah memakai teori Hermeunitika, artinya Arkoun telah mengadakan reinterpretasi terhadap hal-hal yang prinsip dalam Islam.

Pendekatan dekonstruksi yang digunakan Arkoun dalam mengkritik pemikiran-pemikiran ortodoks karya-karya ulama dan Fuqaha yang disinyalir oleh Arkoun sebagai pemikiran dogmatik yang diiringi dengan memberikan kategorisaasi kesahehan, menurut Din Samsudin yang dikutip oleh Iska, bahwa Arkoun selalu mengaitkan dengan realitas sosio historis dan sosio kultural masyarakat. Setelah itu, Arkoun kemudian membangun suatu paradigma pemikiran Islami, sebagai jawaban Islam terhadap tantangan modernitas. ${ }^{10}$ Dengan permasalahan sebagaimana yang dikemukakan diatas dan untuk mengetahui alur pemikiran Mohammad Arkoun secara lebih jauh, pemakalah tertarik untuk melakukan penelitian apa dan darimana sesungguhnya akar epistemologi pemikiran Arkoun serta bagaimana kritik epistemologinya terhadap pemikiran (baca: nalar) Islam ?.

${ }^{8}$ Johan Meuleman dalam Pengantar Nalar Islami dan Nalar Modern..., hlm. 7

9 Pendekatan Dekonstruksi Arkoun ini sejalan dengan ide Jaques Derrida ketika mengkritik pandangan kaum strukturalis dalam menangani suatu teks. Dia berpendapat bahwa tidak ada realita di luar teks, tidak ada makna yang transendental bagi teks-teks yang dianggp suci, adapun pengertian dekonstruksi itu sendiri adalah membebaskan teks dari ketidakjelasan agar kemudian dijelaskan dengan mengungkapkan kontradiksi-kontradiksi yang ada dalam teks tersebut sekaligus melihat sisi kelemahannya. Dengan menganalisis suatu struktur pemikiran berarti telah dilakukan pemahaman baru yang lebih sesuai dengan kondisi, lihat Sukri Iska, Rekontruksi Pemikiran Kritis Arkoun..., hlm. 14.

${ }^{10}$ Sukri Iska, Rekontruksi Pemikiran Kritis Arkoun..., hlm. 14. 


\section{B. Historitas Kehidupan Mohammed Arkoun}

Mohammad Arkoun lahir pada tanggal 2 Januari 1928 dalam keluarga biasa diperkampungan Berber yang berada di sebuah desa di kaki gunung Taorirt-Mimoun, Kabilia, sebelah timur Aljir, Aljazair. Keluarganya berada pada strata fisik dan sosial yang rendah, salah stunya ibunya mengalami buta huruf, dengan bahasa Kabilia Barber sebagai bahasa ibu dan bahasa Arab sebagai bahasa nasional Aljazair. Pendidikan dasar Arkoun ditempuh di desa asalnya, dan kemudian melanjutkan sekolah menengah di kota pelabuhan Oran, sebuah kota utamaa di Aljazair bagian barat yang jauh dari Kabilia.

Kemudian Arkoun melanjutkan studi bahasa dan sastra Arab di Universitas Aljir (1950-19540, sambil mengajar bahasa Arab pada sebuah sekolah menengah atas di al-Harach, yang berlokasi di daerah pinggiran ibukota Aljazair. Pada saat perang kemerdekaan Aljazair dari Perancis (1954-1962), Arkoun melanjutkan studi tentang bahasa dan sastra Arab di Universitas Sorbonne, Paris. Ketika itu dia sempat bekerja sebagai agrege bahasa dan kesusasteraan Arab di Paris serta mengajar di sebuah SMU (Lycee) di Strasbourg (daerah Perancis sebelah timur laut) dan diminta memberi kuliah di Fakultas Sastra Universitas Strasbourg (1956-1969). Pada tahun 1961, Arkoun diangkat sebagai dosen di Universitas Sorbonne, Paris, sampai tahun 1969, disaat dia menyelesaikan pendidikan doktor di bidang sastra pada universitas tersebut. Arkoun menulis desertasi doktor mengenai humanisme dalam pemikiran etis Miskawaih (1030 M), seorang pemikir Arab di Persia pada abad X M yang menekuni kedokteran dan filsafat. Miskawaih dikenal sebagai tokoh yang menguasai segala bidang ilmu dan menekuni persamaan dan perbedaan antara Islam dan tradisi pemikiran Yunani. Semenjak menjadi dosen di Universitas Sorbonne tersebut, Arkoun menetap di Perancis dan menghasilkan banyak karya yang dipengaruhi oleh perkembangan mutakhir tentang Islamologi, filsafat, ilmu bahasa dan ilmu sosial di dunia barat, terutama di dunia tradisi keilmuan Perancis. Jenjang pendidikan dan pergulatan ilmiah yang ditempuh Arkoun membuat pergaulannya dengan tiga bahasa (Berber Kabilia, Arab dan Perancis) dan tradisai serta kebudayaan menjadi semakin erat. 
Di kemudian hari, barangkali inilah yang yang cukup mempengaruhi perhatiannya yang begitu besar terhadap peran bahasa dalam pemikiran dan masyarakat manusia. Ketiga bahasa tersebut sesungguhnya mewakili tiga tradisi, orientasi budaya, cara berfikir dan cara memahami yang berbeda. Bahasa Berber Kabilia merupakan alat untuk mengungkapkan berbagai tradisi dan nilai mengenai kehidupan sosial dan ekonomi yang sudah ribuan tahun usianya, bahasa Arab merupakan alat untuk melestarikan tradisi keagamaan Islamdi Aljazair dan di berbagai belahan dunia Islam lainnnya. Sedangkan bahasa Perancis merupakan bahasa administrasi pemerintahan serta untuk mengenal nilai-nilai dan tradisi keilmuan Barat, terutama Perancis.

Pada tahun 1970-1972 Arkoun mengajar di Universitas Lyon dan kembali lagi ke Paris sebagai guru besar sejarah pemikiran Islam di Universitas Sorbonne, yang sekarang sudah pensiun namun tetap menbimbing karya penelitian di sana. Karena kepakarannya, Arkoun sering diundang untuk memberi kuliah dan ceramah di sejumlah universitas dan institut keilmuan di dunia, termasuk di Indonesia. Di dalam menjalani profesinya sebagai pengajar, Arkoun selalu menyampaikan pendapatnya secara logis berdasarkan analisis yang memiliki bukti dan interaksi filsafati religius, sehingga dapat membangkitkan kebebasan berbicara dan berekspresi secara intelektual, dan tentu saja membuka peluang terhadap kritik.

Selain mengajar, Arkoun juga mengikuti berbagai kegiatan ilmiah dan menduduki jabatan penting di dunia akademis dan masyarakat. Dia menjabat sebagai direktur ilmiah jurnal Arabica, anggota Panitia Nasional Perancis untuk Etika dan Ilmu Pengetahuan Kehidupan dan Kedokteran,anggota Majelis Nasional Perancis untuk AIDS dan anggota Legiun Kehormatan Perancis (chevalier de la Legion d'honneur). Dia ernah mendapat gelar kehormatan, diangkat sebagai Officer des Palmes Academiques, sebuah gelar kehormatan Perancis untuk tokoh terkemuka di dunia universitas dan pernah menjabat sebagai direktur Lembaga Kajian Islam dan Timur Tengah pada Universitas Sorbonne Neuvelle (Paris). Sosok Arkoun yang demikian ini, dapat dinilai sebagai cendekiawan yang engage, melibatkan diri dalam berbagai kegiatan dan aksi yang menurutnya penting bagi kemanusiaan, sebab baginya pemikiran dan aksi harus saling berkaitan.

Sebagai ilmuwan yang produktif, Arkoun telah menulis banyak buku dan artikel di sejumlah jurnal terkemuka seperti Arabica (Leiden/Paris), Studia Islamica (Paris), Islamo- Christiana (Vatican) dan masih banyak lagi di berbagai buku dan ensiklopedia. Arkoun juga menerbitkan kumpulan makalah dan karya bersama yang dilakukan dengan cendekiawan lain. Di antara 
KRITIK ARKOUN ATAS. . karyanya yang penting adalah, Traite d'ethique (tradution francaise avec introduction et notes $d u$ Tabdhib al-Akblaq) (sebuah pengantar dan catatan- catatan tentang etika dari Tahdhib al-Akhlak Miskawaih).

Buku-buku Arkoun yang merupakan kumpulan artikelnya di beberapa jurnal antara lain adalah Essais sur la pensee islamique (Esai-esai tentang pemikiran Islam), dan bukunya yang lain adalah Aspect de le pensee musulmane classique (Aspek-aspek pemikiran Islam Klasik) dan L'islam, religion et societe (Islam, abama dan Masyarakat), dan masih banyak karya-karyanya di samping yang belum diterbitkan, juga beberapa artikel penting di antaranya, "Rethingking Islam Today” dalam buku Liberaal Islam: A Source Book, dan sebagainya.

Karya-karya Arkoun mayoritas dibuat dalam bahasa Perancis, dan kemudian tersebar dalambentuk karya terjemahan ke berbagai bahasa di dunia. Karya-karya Arkoun tersebut bila dicermati ternyata banyak diilhami oleh para ilmuwan Perancis seperti Paul Ricoeur, Michel Fouchault, Jack Derrida, Rolan Barthes dan Piere Bourdieu. Di samping itu juga dipengaruhi oleh ahli bahasa Swiss dan antropolog Inggris, Jack Goody, ahli sastra Kanada, dan sebagainya.

Arkoun terus mencoba pemahaman-pemahaman yang baru tentang Islam dan kaum muslim dengan menggunakan teori-teori mutakhir yang berkembang di dunia Barat moderen. Upaya tersebut dilakukan Arkoun untuk memadukan unsur yang angat mulia dalam pemikiran Islam dengan unsur yang sangat berharga di dalam pemikiran Barat modern (rasionalitas dan sikap kritis). Dengan begitu Arkoun berharap muncul suatu pemikiran yang bisa memberikan jawaban atas berbagai persoalan yang dihadapi oleh kaum muslim akhir-akhir ini dan dapat membebaskan dari belenggu yang mereka buat sendiri.

\section{Akar Epistemologi Pemikiran Mohammed Arkoun}

Perlu pemakalah sampaikan, bahwa yang menjadi mega-proyek Arkoun adalah yang disebutnya sendiri sebagai Naqid al-aql al-Islami (kritik nalar Islam). Kritik nalar Islami ini pada hakekatnya tidak lain adalah kritik epistemologis terhadap pemikiran Islam. Itulah sebabnya titik sentral pemikiran Arkoun terletak pada kata kunci kritik epistemologis. Sebelum memasuki dunia kritik Arkoun tentang epistemologi Islam, pemakalah ingin sedikit mengupas tentang akar epistemolgisnya pemikiran Arkoun. Hal ini dilakukan dengan harapan dapat memperjelas arah pemikiran Arkoun akan nalar kritik Islamnya.

Akar dari epistemologi pemikiran Arkoun, berawal dari kehidupan Arkoun yang tumbuh pada saat pesatnya perkembangan science, baik yang sosial-humaniora maupun ilmu-ilmu alam di 
dunia Barat. Momentum ini tidak disia-siakan dan dibiarkan berlalu tanpa makna. Sehingga tidak aneh kalau dalam setiap tulisannya kental dengan nuansa istilah-istilah ilmu Barat Modern tersebut. ${ }^{11}$ Karena itu, salah satu kritik Arkoun pada pemikiran Islam menurutnya adalah miskinnya pemikiran tersebut dari penggunaan atau pemanfaatan perkembangan ilmu itu. Menurutnya, pemikiran Islam belum membuka diri pada kemodernan dan karena itu pula pemikiran Islam tidak mampu menjawab tantangan yang dihadapi umat Islam kontemporer. Lebih jauh ia menegaskan bahwa perkembangan mutakhir ilmu-ilmu Barat tersebut belum diterima di kalangan kaum muslimin. Akibatnya pemikiran Islam masih bersifat naif. ${ }^{12}$ Dalam lingkungan Islam, memang ilmu-ilmu sosial modern masih dianggap sebagai ilmu hantu, bukan ilmu inti dan inilah yang menjadikan ilmu-ilmu Islam menjadi kering nuansa dan lebih bersifat 'melangit' serta seringkali bersifat utopis.

Berangkat dari keprihatinan itu maka tidak aneh kalau Arkoun banyak menggunakan pendekatan dan metodologi berbagai cabang ilmu sosial yang ada, dari mulai antropologi, sosiologi, sejarah, linguistik dan filsfat. Ia beranggapan bahwa ilmu-ilmu tersebut telah memberi andil untuk memotret dan memetakan kembali kinerja keilmuan dan pengalaman manusia dalam segala bidang. ${ }^{13}$ Ilmu-ilmu sosial tersebut, menurutnya juga bisa digunakan untuk memahami endapan kesadaran dan keyakinan yang mengatur perilaku masyarakat serta mencapai pembacaan realitas secara langsugn dan total. ${ }^{14}$ Latar belakang pemanfaatan terhadap ilmu-ilmu tersebut bertitik tolak dari paradigmanya bahwa: menggunakan akal guna mempertebal iman. ${ }^{15}$

Dari sekian banyak khazanah keilmuan sosial Barat modern tersebut yang kerap muncul dan dijadikan pisau analisis Arkoun berasal dari filsuf-filsuf Perancis, seperti Paul Ricour, Michel Foucault, Jacques Derrida (antropolog Perancis), Pierre Bourdieu dari Inggris, Jack Gody (ahli bahasa Swis), Ferdinand de Saussure (ahli semiotika Perancis), Roland Barthes dan ilmuwan kesusasteraan Kanada, Northrop Frye. Istilah-istilah yang mereka gunakan dipakai oleh Arkoun untuk mengurai teks-teks (termasuk al-Qur'an) dan produk-produk pemikiran Islam lainnya. ${ }^{16}$ Yang perlu dicatat di sini adalah bahwa Arkoun tidak secara keseluruhan mengambil 'ide-ide'

11 Waryono Abdul Ghafur, al-Qur'an dan Tafsirnya dalam Perspektif Arkoun dalam Studi Al-Qur'an Kontemporer (ed) Abdul Mustaqim Sahron, (Yogyakarta: Tiara Wacana), 2002, hlm. 167-182.

12 Johan Hendrik Meukmin, Nalar Islami dan Nalar Modern: Memperkenalkan Pemikiran Arkoun, dalam jurnal Ulumul Qur'an No. 4 vo. VI th. 1993, hlm. 97.

13 Amin Abdullah, "Arkoun dan Kritik Nalar Islam" dalam Meuleman (penyunting) Tradisi, Kemodernan dan meta Modernisme, (Yogyakarta: LkiS), 1996, hlm. 13.

${ }^{14}$ Mohammed Arkoun, Berbagai Pembacan Qur'an (terj) Mochasin (Jakarta: INIS), 1997, HLM. 48

15 Waryono Abdul Ghofur, Al-Qur'an dan Tafsirnya..., hlm. 171.

16 Waryono Abdul Ghofur, Al-Qur'an dan Tafsirnya..., hlm. 170. 
Barat tersebut. Ia terkesan hanya mencomot sebagian dan terkadang memaknainya dengan pengertian sendiri. ${ }^{17}$

Dengan itu semua Arkoun membangun teori dan pemikirannya kemudian melakukan kritik terhadap seluruh bangunan pemikiran Islam. Bila melihat itu semua maka yang ingin dibangun Arkoun adalah sebuah kritik terhadap bangunan epistemologis yang bertujuan bukan hanya mendekonstruksi tanpa ada tujuan. Dengan itu maka akan tampak keterkaitan antara bahasa, pemikiran, ideologi dan sejarah. Dengan menempatkan seluruh bangunan keilmuan pemikiran pada tataran historis, maka semuanya tidak ada yang sakral, bisa dikritik dan berubah serta dibongkar. Dengan demikian ia menekankan perlunya mempertimbangkan aspek ruang dan waktu dalam memahami pemikiran. Dengan demikian historisme berperan untuk merekonstruksi makna lewat penghapusan relevansi antara teks dan konteks dan jika metode ini diaplikasikan pada teks-teks keagamaan, maka makna baru yang secara potensial bersemayam dalam teks-teks tersebut akan muncul.

Arkoun menjelaskan bahwa ia menyukai pendekatan historis, sosiologis dan antropologis dengan perspektif epistemologi baru. Menurutnya, hanya dengan pendekatan-pendekatan tersebut dapat dilakukan pembebasan Islam dari postulat-postulat esensialis dan substansialis metafisika klasik. Dan dengan pendekatan itu semua bukan berarti ia -katanya- mengabaikan pendekatan teologis dan filosofis, tapi untuk memperkayanya. Sedangkan metode yang digunakannya adalah dekonstruksi. Strategi dekonstruksi hanya mungkin dicapai dengan epistemologi baru tersebut. Untuk nalar perlu dibebaskan dari ontologi, transendentalisme dan substansialisme yang memenjarakannya. ${ }^{18}$ Dengan kata lain untuk rekonstruksi (konteks) harus ada dekonstruksi (teks). Karena itu, bagi Arkoun pertanyaan epistemologis yang paling mendasar adalah "Bagaimana seseorang bisa mengetahui apa yang terjadi pada masyarakat lama atau kontemporer. ${ }^{\text {19 }}$

\section{Epistemologi Islam dalam Kritik Mohammed Arkoun}

Mengutip pendapat Amin Abdullah, titik sentral pemikiran Arkoun terletak pada kata kunci kritik epistemologis. Pemahaman dan makna kritik epistemologis dalam konsepsi Arkoun

17 Waryono Abdul Ghofur, Al-Qur'an dan Tafsirnya..., hlm. 172 - 179. Sebagai contoh dalam Konsep mitos Arkoun memakai pandangan Ricour, dalam konsep linguistik Arkoun memakai konsep Semiotika de Sassure dan Bertems. Dalam analisis Semiotiknya Arkoun memakai konsep Derrida dan Seussure dan dalam teori dekonstruksinya Arkoun memakai konsep dekonstruksi Derrida, serta konsep epistemologi dalam memahami teks Arkoun memakia konsepnya Faucault.

18 Waryono Abdul Ghofur, Al-Qur'an dan Tafsirnya..., hlm. 179

${ }^{19}$ Robert D. ke mencari Islam Autentik (terj) Ahmad Balquni, (Bandung: Mizan), 2000, hlm. 170 
terasa lebih menukik dan menyengat karena kritik epistmologisnya ditujukan pada bangunan "keilmuan" ilmu-ilmu agama secara keseluruhan. Struktur bangunan keilmuan agama (Islam) dilihatnya sebagai produk sejarah pemikiran keagamaan biasa yang hanya berlaku pada penggal waktu dan ruang tertentu. ${ }^{20}$

Meskipun nilai-nilai dan ajaran agama Islam sering disebut Salib Li Kullizaman Wa Makan, tetapi jika nilai-nilai tersebut dipraktekkan dalam kehidupan masyarakat tertentu, yang nota bene terkurung oleh kepentingan sosial politik ekonomi tertentu, maka nilai tersebut tidak lagi bersifat transendental universal dalam artian sebenarnya, atau boleh dikata "mau tidak mau warna (baca: muatan lokal) juga ikut membentuknya. ${ }^{21}$

Selain hal di atas Arkoun menilai bahwa umat Islam terpaku pada kajian-kajian teks klasik, dan berhenti pada makna-makna eksplisit yang tertuang dalam teks tersebut, tanpa mencoba melanjutkan dengan suatu analisa mengenai informasi implisit yang tersirat di dalamnya. ${ }^{22}$ Bahkan budaya kritik epistemologis, khususnya dalam wilayah pemikiran keagamaan tidak tumbuh secara wajar dalam budaya muslim, sehingga yang terjadi adalah apa yang diistilahkan Arkoun sebagai proses pensakralan atau pensucian buah pikiran keagamaan. ${ }^{23}$

Dalam ungkapan lain Arkoun menyebut, pemikiran Islam yang ada pada umumnya belum lagi membuka diri pada kemodernan pemikiran. Keadaan ini terjadi karena pemikiran umat Islam dari kebanyakan, cenderung dalam mendekati agama hanya atas dasar kepercayaan langsung tanpa kritik. Padahal makna-makna wahyu ilahi yang diaktualisasikan umat Islam pemula didahului oleh faktor sosial, budaya, psikis, politik dan sebagainya. Sehingga apa yang terjadi sekarang umat Islam terkesan tidak dapat menjawab tantangan yang dihadapi umat Islam kontemporer. ${ }^{24}$

Kritik Arkoun terhadap epistemologi Islam, tidak lain hanyalah bertujuan sebagai pembebasan nalar Islami dari kejumudan, keterbatasan dan ketertutupan, sehingga Islam kembali menjadi sarana emansipasi umat manusia. Tujuan tersebut, menurut hemat Arkoun dapat dicapai jika pemikiran Islam membuka diri pada berbagai perkembangan mutakhir dari pemikiran

${ }^{20}$ Amin Abdullah, Arkoun dan Kritik Nalari Islam, dalam J. H. Meuleman (penyunting) Tradisi Kemodernan dan Meta Modernisme..., hlm. 5

${ }^{21}$ Amin Abdullah, Arkoun dan Kritik Nalari Islam, dalam J. H. Meuleman (penyunting) Tradisi Kemodernan dan Meta Modernisme..., Ibid., hlm. 6

22 Johan Meuleman, Islam dan Pasca Modernisme Kemodernan Pandangan Arkoun, dalam J.H. Meuleman (penyunting) Tradisi Kemodernan dan Meta Modernismme..., hlm. 119-130.

23 Amin Abdullah, Arkoun dan Kritik nalar..., hlm. 7.

${ }^{24}$ Syukri Iska, Rekonstruksi Pemikiran Kritis Arkoun, dalam Jurnal Ta'dib vol. 2 no. 20 hlm. 17. 
modern. Dengan kata lain Arkoun mencita-citakan suatu pembangunan unsur paling berharga dari nalar Islami dan dari nalar Modern. ${ }^{25}$ Menengok tujuan diatas, Arkoun dengan kritik epistemologisnya berarti ingin meruntuhkan doktrin-doktrin agama Islam yang sudah pokok. Namun Arkoun ingin membidik analisisnya terpusat pada "konstruksi" "konsepsi epistemologi" atau metodologi yang dahulu digunakan oleh kreativitas para penemu, penyusun dan mencetus ilmu-ilmu agama Islam (seperti : Fiqih, Ilmu kalam dan sebagainya) era klasik skolastik. Dalam bahasa sederhananya Amin Abdullah, Arkoun ingin menerjemahkan kembali serta merinci kembali dengan cara lain apa yang telah dinyatakan oleh para pendahulunya. ${ }^{26}$

Kritik epistemologi yang dicanangkan oleh Arkoun terhadap konsepsi dan bangunan keilmuan agama Islam bukanlah bertuuan untuk sekedar melakukan pembongkaran tanpa tujuan, yakni pembongkaran untuk pembongkaran itu sendiri. Menurut hematnya, hanya lewat cara demikianlah umat Islam dapat disadarkan kembali akan adanya keterkaitan dan pertautan “bahasa-pemikiran-sejarah” yang erat. Manusia beragama perlu sadar sepenuhnya akan adanya pertautan yang berbentuk lingkaran tanpa putus, antara ketiga komponen tersebut. Tidak ada "konsepsi" keberagaman apapun, selagi itu masih disebut "konsepsi" yang terlepas sama sekali dari ketiga komponen tersebut. Jika itu disadari, maka akan dimungkinkan adanya kritik pemikiran keagamaan, pluralitas pemahaman keagamaan Islam, autentisitas dan dinamika pemikiran, kontekstualisasi sejarah, dan begitu seterusnya. Dengan begitu, pemikiran keagamaan Islam akan bersifat terbuka, dialogis, tidak mapan, baku dan standar. ${ }^{27}$

\section{E. Analisis Terhadap Kritik Arkoun Atas Epistemologi Nalar Islam}

Dari uraian di atas, kiranya dapat penulis simpulkan bahwa Muhammed Arkoun adalah sosok pemikir Islam yang pemikiran-pemikirannya berbeda jauh di depan state of affair (keadaan) dunia Islam saat ini. Dengan menggunakan metodologi dari berbagai ilmu pengetahuan kontemporer yang berkembang di dunia Barat, Arkoun melakukan proyek besar yang disebutnya sendiri dengan Naqd Al-Aql Al-Islami (kritik nalar Islami), yang pada hakekatnya tidak lain adalah kritik epistemologis terhadap pemikiran Islam. Arkoun dalam kajiannya bertindak sebagai pengkritik pemikiran Islam, yakni penelitian mengenai dasar dan batas pemikiran, atau dengan kata lain mengenai syarat-syarat kesahihan pemikiran tertentu.

Kegelisahan Arkoun yang mewarnai hampir seluruh pemikirannya adalah kenyataan adanya dikotomi-dikotomi di dalam masyarakat, khususnya masyarakat muslim.

25 Johan Meuleman, Islam dan Pasca Modernisme..., hlm. 119.

26 Amin Abdullah, Arkoun dan Nalar Kritik Islam..., hlm. 15 - 16.

27 Amin Abdullah, Arkoun dan Nalar Kritik Islam..., hlm. 16 - 17. 


\section{SOLIKHIN DAN M. FADHOLI}

Dikotomi-dikotomi tersebut secara garis besar banyak bersentuhan dengan persoalan- persoalan particularity vs universality, dan marginality vs centrality. Problem-problem ini tampak tercermin dari adanya pembagian-pembagian dunia secara berhadap-hadapan, seperti Sunni dengan Syï, kaum mistik dengan kaum tradisionalis, muslim dengan non- muslim, Berber (non-Arab) dengan Arab, Afrika (Asia) dengan Eropa dan sebagainya. Oleh karena itu, dunia yang dituju oleh Arkoun adalah dunia yang tidak berpusat, tidak ada pinggiran, tidak ada kelompok yang mendominasi, tidak ada kelompok yang terpinggirkan, tidak ada kelompok yang superior dan tidak ada kelompok yang inferior dalam menghasilkan sebuah kebenaran. Arkoun berusaha mengajukan pertanyaan yang kritis kepada kita, yaitu "Bagaimana seluruh manusia bisa menjadi diri mereka sendiri dan dengan identitas mereka sendiri tampa menyendiri dari tetangga dan sesama manusia lainnya?" Bagi orang Islam, Arkoun bertanya-tanya, "Dapatkah identitas muslim itu didamaikan dengan identitas non-muslim?" Satu hal yang menjadi kelemahan Arkoun menurut pemakalah adalah bahwa Arkoun terkesan lebih memaksakan pendekatan ataupun alat analisis yang digunakannya sehingga tidak adanya konsistensi (hanya mencomot dari beberapa tokoh yang dianggapnya sesuai) dalam kritik nalar Islaminya. Selain itu menurut pemakalah Arkoun hanya sebatas kritik yang tanpa mengiringi hasil kritikannya dengan solusi kongkritnya.

Mengapa kritik epistemologi? Sebagai seorang pemikir yang lahir dan dibesarkan di dunia Islam, al-Jazair, dan mengenyam pendidikan di Perancis, Arkoun sangat merasakan keterbelakangan dunia Islam dibandingkan dengan dunia Barat dalam berbagai bidang kehidupan. Keterbelakangan ini menurut Arkoun disebabkan oleh kebekuan dan ketertutupan pemikiran Islam. Kebekuan dan ketertutupan pemikiran Islam inilah yang dilukiskan oleh Arkoun sebagai fenomena Taqdis Al-Afkar Al-Diniyyah.

Dengan demikian persoalan mendasar yang menyelimuti umat Islam, menurut Arkoun adalah persoalan yang lebih bersifat epistemologis. Oleh karena itu, dengan kritik epistemologis yang dilakukannya, kebekuan, dan ketertutupan pemikiran Islam diharapkan dapat dicairkan dan dibuka, sehingga pada gilirannya akan mampu menjawab tantangan yang dihadapi umat Islam di dunia modern serta menjadi sarana emansipasi manusia. Dalam fenomena Taqdis Al-Afkar AlDiniyyah, Arkoun melihat bahwa umat Islam tidak menyadari sepenuhnya letak tempat Islam sebagai wahyu dan letak tempat Islam sebagai pemikiran Islam. Kritik epistemologis Arkoun dimaksudkannya untuk menunjukkan posisi tersebut secara proporsional. Dalam rangka inilah Arkoun membedakan antara dua bentuk teks, yakni teks pembentuk dan teks penafsir. Pemikiran 
KRITIK ARKOUN ATAS... Islam dalam berbagai bentuknya adalah merupakan teks penafsir. Pemikiran Islam sebagai upaya penafsir (hermeunitis) terhadap Islam sebagai wahyu, tidak bisa lepas dari berbagai pengaruh politik, sosial, maupun kultural. Dengan demikian pemikiran Islam selalu bersifat historis. Karena itulah pemikiran Islam tidak bisa mewakili kompleksitas Islam sebagai wahyu yang bersifat transhistoris.

Metodologi dam pendekatan yang dilakukan oleh Mohammed Arkoun, sedikit banyak telah dipengaruhi oleh dua kekuatan tradisi pemikiran yang telah ada, yaitu tradisi pemikiran budaya Timur Tengah Kuno yang memilik tempat khusus di dalam pemikiran Yunani dan tardisi pemikiran monoteisme yang dibawa oleh para nabi. Sehingga Arkoun mengemukakan bahwa dirinya sebagai pengguna metodologi historis-kritis yang mencoba merespon rasa keingintahuanny secara modern, karena metodologi ini nilainya dapat menelusuri studi tentang pengetahuan mistis yang tidak hanya dibatasi dengan mentalitas lama.

Dengan demikian, menurut Arkoun, saat ini usahaa intelektual utama yang harus dipresentasikan secara luas ke dalam pemikiran tentang Islam dan tentang agama lainnya adalah bagaimana mengevaluasi karakteristik-karakteristik dari sistem ilmu pengetahuan yang historis dan mistis dengan perspektif epistimologis yang baru. Tujuan yang ingin diraih dengan proyek ini adalah untuk mengembangkan sebuah strategi epistimologi baru di bidang studi perbandingan terhadap budaya melalui contoh yang dikembangkan oleh Islam sebagai agama dan sebagai produk sosial sejarah. Arkoun mengajukan pendekatan historis, sosiologis, dan antropologis dengan tidak menghilangkan betapa pentingnya pendekatan teologis dan filosofis. Dan pendekatan yang dilakukan oleh Arkoun ini bertujuan untuk memperkaya pendekatan tersebut dengan memasukkan keadaan-keadaan historis dan sosisl yang selalu dipraktekkan dalam Islam.

Metode Arkoun ini disebut sebagai salah satu bentuk metode dekonstruksi. Strategi dekonstruksi tersebuthanya mungkin dilakukan dengan epistimologi modern yang kritis. Dengan demikian, nalar kritis seseorang harus dibebaskan dari ontologi, transendentalisme, dan substansionalisme yang mengikat, membatasi kebebasan dan memenjarakannya, terutama di dalam nalar yang dielaborasikan di berbagai macan teologi melalui metafisika dan logika Yunani. Di dalam melaksanakan proyek besar tersebut, menurut Arkoun harus dimulai dari suara atau teori yang dianggap Arkoun memiliki otoritas, karena hanya dia yang dapat memberikan penampakan Islam dan mentalitas modern yang ilmiah, dan sekaligus juga di dalam pengalaman keagamaan orang Islam. Dalam bahasa lain, agar kita dapat mengartikulasi visi modern tentang Islam yang sekaligus bisa memberikan pada komunitas. Dengan demikian, fungsi kritik 
epistemologis Arkoun, adalah bentuk menunjukkan historisitas dari pemikiran Islam. Ada hubungan yang erat, yang bersifat circular tanpa putus, antara pemikiran, bahasa, dan sejarah. Tidak ada pemikiran apapun yang terlepas sama sekali dari ketiga komponen tersebut.

Dengan dapat ditunjukkan historisitas yang ada dalam pemikiran Islam ini, umat Islam diharapkan dapat menyadari sepenuhnya adanya pluralitas dan relativitas dalam pemikiran Islam. Jadi dengan kritik epistemologisnya, Arkoun melakukan desakralisasi dan relativisasi terhadap pemikiran Islam. Apabila pluralitas dan relativitas pemikiran Islam itu disadari oleh umat Islam, maka fenomena seperti Taqdis Al-Afkar Al-Diniyyah akan tercerahkan, sehingga tidak ada lagi klaim kebenaran yang berlebihan dalam diri umat Islam baik secara kelompok, indifidu maupun antar organisasi. Sehingga akan membawa implikasi terhadap keberagamaan Islam masa depan, menuju kepada keberagamaan yang terbuka dan dialogis. Dengan keberagamaan yang terbuka dan dialogis inilah, umat Islam diharapkan dapat menjawab tantangan zaman. Dengan memberikan tawaran pemecahan terhadap berbagai problem, yang tidak saja dihadapi oleh umat Islam saja, tetapi juga yang dihadapi oleh umat yang lain. Sehingga kejayaan Islam akan terwujud sebagaimana Islam pada masa awal.

\section{F. Penutup}

Dari uraian tersebut jelaslah, bahwa dengan cara membongkar bangunan epistimologi keilmuan agama Islam, Arkoun ingin mengembalikan wacana dan dataran qur-ani yang lebih mendasar, mendalan dan substansial. Pada sebuah wacana yang memuat nilai-nilai normatif, spiritualis, dan moralitas keberagaman Islam yang terbuka, mendasar, sekaligus fungsional, tanpa harus dibebaniterlalu berat dan muatan ideologi politik. Untuk melihat dan mengungkap kembali autentitas spiritualis dan moralitas keberagaman Islam, seorang muslim harus berani melakukan "pembongkaran" terhadap struktur tersebut dengan menyimak kembali ajaranajaran Islam yang lebih arif dan komprehensif. 


\section{Daftar Pustaka}

Arkoun, Muhammad, 2005, Islam Kontemporer Menuju Dialog Antar Agama (terj: Ruslani), Yogyakarta: Pustaka Pelajar. , 1988, Pemikiran Arab (terj: Yudian W), Yogyakarta: Pustaka Pelajar Offset. 1997, Berbagai Pembacaan Qur'an (terj: Machasin), Jakarta: INIS.

Jurnal Studi Ilmu-ilmu Al-Qur'an dan Hadis, Januari 2005, vol. 6, No. 1.

Jurnal Ta'dib, 1999, vol 2, No. 2.

Jurnal Ulumul Qur’an, 1993, No. 4 vo. VI.

Meuleman, Johan (peny), 1994, Nalar Islami dan Nalar Modern: Berbagai tantangan dan Jalan baru, Jakarta: INIS.

1996, Tradisi, Kemodernan, dan Metamodernisme: Memperbincangkan Pemikiran Mohammed Arkoun, Yogyakarta: LkiS.

Mustaqim, Abdul (ed), 2002, Studi Al-Qur'an Kontemporer, Yogyakarta: Tiara Wacana.

Rahman, Fazlur, 1992, Islam (terj: Senoaji Saleh), Jakarta: Bumi Aksara.

Robert D., 2000, Mencari Islam Autentik (terj) Ahmad Balquni, Bandung: Mizan.

Sofyan, Muhammad, 2006 , Jalan Ketiga Pemikiran Islam, Yogyakarta: Ircisod. 